\title{
Conditioned Export-Led Growth Hypothesis: A Panel Threshold Regressions Approach
}

\author{
Fernando Seabra ${ }^{1}$ \\ Jaqueson Kingeski Galimberti ${ }^{2}$
}

\begin{abstract}
This paper deals with a reassessment of the export-led growth hypothesis on a panel threshold regressions context which allows testing for the existence of other variables conditioning the effects on the exports-growth nexus. The estimation covers a broad sample of 72 countries for the period 1974-20o3. Overall, the empirical results give support to the export-led growth hypothesis, where the estimated thresholds indicate that growth was conditioned by countries initial levels of output and human capital. The effects of exports on growth, although exhibiting diminishing returns, were found to have great relevance in accelerating the process of income convergence across countries.
\end{abstract}

Key-words: export-led growth; panel threshold regressions; trade and growth.

Resumo: O presente artigo trata de uma reavaliação da hipótese de crescimento promovido por exportação baseado no contexto de regressões em painel com efeito threshold - o qual permite que se teste se outras variáveis também condicionam a relação exportação e crescimento. A estimação refere-se a uma amostra ampla de 72 países para o período 1974-2003. Os resultados empíricos comprovam a hipótese de crescimento promovida por exportações, onde os efeitos threshold estimados indicam que o crescimento foi condicionado pelos níveis iniciais de produto e de capital humano de cada país. Os efeitos da exportação sobre crescimento, embora exibam retornos decrescentes, foram encontrados como tendo significativa relevância para acelerar o processo de convergência de renda entre os países.

Palavras-Chave: Crescimento por exportação; regressões com efeito threshold.

JEL: F43; O11; O40.

\footnotetext{
1 Professor do Departamento de Economia da Universidade Federal de Santa Catarina (UFSC). E-mail: seabra@cse.ufsc.br

2 Professor da University of Manchester (UK). E-mail: jaqueson.galimberti@postgrad.manchester.ac.uk
} 


\section{Introduction}

The export-led growth (ELG) hypothesis stands that those countries following an outward-orientation strategy tend to obtain superior growth performances. Edwards (1991) argues that the main channel linking trade and growth can be traced back to an original contribution by Lewis (1955), which basically relates the increase in trade with the higher capacity for a developing nation to absorb technological innovations. This insight can be formalized as a "learning-bylooking" type of process where the mere contact with newer commodities and technologies increases the innovations absorption efficiency, which is the general idea behind the models of Edwards (1989), and, Grossman and Helpman (1991). Another common way of modeling Lewis insight is provided by Feder (1983) who considers the possibility of externality effects from the outward-oriented production, which is exports, to the overall economy.

The empirical literature on the trade-growth relationship has mainly focused on robustness tests of results indicating the existence of a positive effect from exports to growth, especially in cross-country studies (for a survey on empirical works, see Giles and Williams, 2000). Although trade liberalization does not necessarily imply exports growth, in practice they appear to be highly correlated. Moreover, the effect of trade liberalization on economic growth tends to occur mainly through efficiency improvements and exports stimuli that have powerful effects on both supply and demand within an economy (Thirlwall, 2000, p. 14).

According to Giles and Williams (2000), the empirical literature on the ELG hypothesis may be separated into three groups. Early studies used crosscountry correlation coefficients between exports and growth. Also relaying on the cross-country analysis the follower studies consisted of LS-based regression applications. The third group of works applied various time series techniques, such as causality and cointegration, to examine the exportsgrowth nexus usually based on individual country analysis. We add three other groups of studies to this classification. First, some recent studies have emerged concerning the importance of the composition of exports, as Fosu (1990), Funke and Ruhwedel (2001), Crespo-Cuaresma and Wörz (2005), and Herzer et al. (2006), between others. Second, another group of studies have applied recent techniques of causality for panel data, as Ahumada and Sanguinetti (1995), and Kónya (2006). Finally, the last group of works, on which this work is included, is represented by the work of Foster (2006) who proposes the use of threshold regression techniques to examine whether any relationship between exports and growth depends upon a third variable.

Focusing on a comprehensive sample of African countries Foster (2006) founds statistically significant thresholds in the relationship between growth and exports where these thresholds were determined by the countries' initial 
level of GDP per capita, the share of exports in GDP, and the growth of exports. The threshold approach also allowed the conclusion that the effect of exports on GDP growth is larger in those countries with relatively lower initial level of income, lower level of exports to GDP, and higher exports growth rate.

Therefore, the objective of this paper is to extend the Foster (2006) model to account for a larger sample and for different threshold alternatives. That is, the aim of this study is to assess what we decided to call the "conditioned" export-led growth hypothesis, using panel threshold regression (PTR) techniques and assuming three different threshold variables: the initial level of GDP per worker, the human capital per capita level, and the exports share in GDP. The sample comprises 72 countries and data ranges from 1974 to 2003 . Additionally, special attention is given to the construction of human capital measures using an alternative specification that accounts for educational quality differentials between countries.

The paper is organized as follows. Section II discusses the econometric methodology, the results are in Section III and in Section IV we present some concluding remarks.

\section{Econometric Methodology}

\subsection{Panel Data Approach to Economic Growth}

One of the first advocates of the panel data approach on the empirics of economic growth was Islam (1995). Focusing on the process of convergence the author argues that allowing for differences in the production function across countries, in the form of fixed individual country effects, the panel data approach allows to isolate the effect of capital deepening on the one hand, and, technological and institutional differences on the other. Thus, the specification of individual country effects came as a potential solution for the omitted variables problem in the framework of single cross-country and pooled regressions. Moreover, in a dynamic context, the usage of lagged regressors as instruments seems to alleviate measurement error and endogeneity biases (Temple, 1999, p. 131-132). The panel specification of most growth studies can be summarized in the following form:

$$
y_{\mathrm{i}, \mathrm{t}}=\beta_{1} y_{\mathrm{i}, \mathrm{t}-1}+\beta_{2} y_{\mathrm{i}, \mathrm{t}}+\mu_{\mathrm{i}}+\eta_{\mathrm{t}}+\varepsilon_{\mathrm{i}, \mathrm{t}},
$$

where $\dot{y}_{i, t}$ is the average growth rate over a series of five or ten-years period, $X_{i, t}$ is a vector of explanatory variables $\mu_{i}$, and $\eta_{t}$ are the country and time specific effects, $\varepsilon_{i, t}$ is a serially uncorrelated measurement error, and the subscripts $i$ and $t$ refer to country and period, respectively. 
As the individual country effects term may be correlated with the explanatory variables the random effects specification, which is assumed to be uncorrelated with the exogenous variables, is generally not considered. The estimation techniques used to remove the fixed effects includes the within group estimator, and the generalized method of moments estimator (GMM). The first one requires a time series demeaning procedure, subtracting from each variable their within group means, while in the GMM the general approach is to estimate the equation in differences and to remove the country specific effects by using lagged levels of the regressors as instruments. (Capolupo, 2009)

However, the adoption of the panel data approach also has its own weaknesses: (i) the range over which average of variables are computed is shorter compared to cross-country studies, and hence, not adapted to capturing long run effects; (ii) the use of differenced variables changes the interpretation of regression results; (iii) some unjustifiable assumptions about parameter homogeneity; (iv) the problem of serial correlation in the errors needs to be further explored. Notice that the threshold regressions approach to be outlined below comes as an alternative to alleviate the pitfalls originated from these issues, specially the third.

\subsection{Panel Threshold Regressions Model}

Threshold regression models allow individual observations to be divided into regimes based on the value of an observed variable. Firstly introduced into univariate time series context (Tong, 1983), the seminal paper of Hansen (1999) introduced the econometric techniques appropriate for threshold regression with panel data. Allowing for fixed individual-effects the PTR model divides the observations into two or more regimes depending on whether a threshold variable is smaller or larger than a threshold value, and these regimes are distinguished by differing regression slopes.

From panel data of a dependent variable $y_{i, t}$, a vector of regressors $x_{i, t}$, a threshold variable $q_{i, t}$, and a threshold value of $\gamma$, the structural equation of interest is specified in the following eq. (2):

$$
y_{i, t}=\mu_{i}+\beta^{\prime}{ }_{1} x_{i, t} I\left(q_{i, t} \leq \gamma\right)+\beta^{\prime}{ }_{2} x_{i, t} I(q i, t \leq \gamma)+\varepsilon_{i, t}
$$

where $I(\bullet)$ is the indicator function which assumes the value of one (1) when the inner brackets condition is satisfied and zero (o) otherwise, $\mu_{i}$ is the fixed individual-effect, and $\varepsilon_{i, t}$ is independent and identically distributed (i.i.d.) error term with mean zero and finite variance $\sigma^{2}$. 
It is easy to see that the point estimates for the slope coefficients $\beta^{\prime} s$ are dependent of the given threshold value $\gamma$. Since the threshold value is not previously known and it is supposed to be endogenously determined, Hansen (1999) recommends a grid search selection of $\gamma$ that minimizes the sum of squared errors (SSE) obtained by least squares estimates of equation (3.1). Moreover, it is undesirable for a threshold $\gamma^{\prime}$ to be selected which sorts too few observations into one or the other regime, and so, it is also suggested that the search for the SSE minimizing threshold value to be restricted by eliminating the smallest and largest $\eta / \%$ values of the threshold variable $q_{i, t}$ for some $\eta>0$. On the threshold autoregressive time series models context, Enders (2004, p. 397) suggests to exclude the highest and lowest 15 percent, while Hansen (1999, p. 349) suggests to exclude 1 or 5 percent on the PTR models context.

After finding the estimate for the threshold value $\gamma$ it is important to infer whether the threshold effect is statistically significant, which is equivalent to test the null hypothesis that $\beta^{1}=\beta^{2}$. However, as the threshold $\gamma$ is not identified under the $\mathrm{H}_{0}$, classical tests have non-standard distributions. At this point, Hansen (1996) suggested a bootstrap procedure to simulate the asymptotic distribution of the likelihood ratio test of eq. (3). Details about this procedure can be found at Hansen (1999, p.350-1). The null of no threshold effect is rejected if the $\mathrm{p}$-value obtained by the bootstrap procedure is smaller than the desired critical value.

$$
F_{1}=\frac{S_{0}-S_{1}\left(\gamma^{\prime}\right)}{\sigma^{\prime^{2}}}
$$

where $S_{o}$ is the SSE obtained from the estimative of (2) under the null hypothesis of no threshold, $S_{1}$ is the SSE obtained from the PTR estimative of (2), and $\sigma^{\prime 2}$ is the residual variance of the PTR regression.

Once the threshold effect is found to be significant, one would ask if the estimated $\gamma^{\prime}$ is consistent for the true value of the threshold $\left(\gamma_{0}\right)$. To form confidence intervals for $\gamma^{\prime}$, Hansen (1999, p. 351) proposes the likelihood ratio statistic reproduced in equation (4), which under some technical assumptions has the critical values of 5.94, 7.35, and 10.59, at the significance levels of $10 \%, 5 \%$, and $1 \%$, respectively.

$$
L R_{1}(\gamma)=\frac{S_{1}-S_{1}\left(\gamma^{\prime}\right)}{\sigma^{\prime 2}}
$$


Hansen (1999, p. 353) also extends the PTR model to test for multiple thresholds. The general approach is quite the same for the case of only two regimes, with just a few differences. The first one refers to the estimation procedure, which may be done by a three-stage (when there is only three regimes) sequential estimation of the two threshold parameters. The first stage refers to the same estimation procedure as presented for the single threshold model, which yields the first estimate $\gamma^{\prime}{ }_{1}$. Fixing this threshold parameter, the second stage estimates the second threshold parameter $\gamma_{2}^{\prime}$ minimizing the SSE of eq. (5). In the last stage, the first threshold parameter is re-estimated holding fixed the second threshold parameter. From this threestage sequential estimation results the asymptotically efficient estimator of the threshold parameters, $\gamma^{\prime}{ }_{1}$ and $\gamma^{\prime}{ }_{2}$. Note that these estimators have the same asymptotic distributions as the threshold estimate in a single threshold model, which means that we can construct confidence intervals in the same way as we did before.

$$
y_{i, t}=\mu_{i}+\beta^{\prime}{ }_{1} x_{i, t} I\left(q_{i, t} \leq \gamma_{1}\right)+\beta^{\prime}{ }_{2} x_{i, t} I\left(\gamma_{1}<q_{i, t} \leq \gamma_{2}\right)+\beta^{\prime}{ }_{3} x_{i, t} I\left(\gamma_{2}<q_{i, t}\right)+\varepsilon_{i, t}
$$

The second difference refers to the inference over the thresholds estimates. When the null of no threshold is rejected with the $F_{1}$ statistic, one needs a further test to discriminate between one and two thresholds. This test is done with a similar bootstrap procedure, but now simulating the distribution of the $\mathrm{F}_{2}$ statistic (Eq. 6).

$$
F^{2}=\frac{S^{1}\left(\gamma^{\prime 1}\right)-S^{\prime 2}\left(\gamma^{\prime 2}\right)}{\sigma^{\prime 2}}
$$

where $S_{1}$ is the SSE obtained from the first-stage estimative, $S_{2}{ }^{r}$ is the SSE obtained from the second-stage estimative, and $\sigma^{\prime 2}$ is the residual variance of the second-stage estimative.

Finally, as González, Teräsvirta and van Dijk (2005) did outlining a three stage process for model building in the context of the panel smooth transition regression (PSTR) models, we outline our model building method for PTR models in three stages: specification, estimation and evaluation. On the specification stage we must test for the existence of thresholds against the linear hypothesis, also determining the appropriate number of thresholds. The second stage consists of the estimation of the selected models from the previous stage. Lastly, we evaluate the results calculating the confidence intervals for the threshold parameters, and confronting the estimated slope coefficients with the economic theory predictions. 


\subsection{Empirical Specification}

The general empirical specification to be estimated can be expressed as in equation (7). In the form of a PTR specification, the regime-dependent coefficient is the one related to the ELG hypothesis. Notice that this general specification reduces to the linear case when the threshold is always smaller or larger than the threshold value.

$$
Y_{i, t}=\beta_{1} y_{i, t-1}+\beta_{2} i i, t+\beta_{3} n i, t+\beta_{4} h i, t+\delta_{1} x i, t I(q i, t \leq \gamma)+\delta 2 x i, t I(q i, t>\gamma)+\mu_{i}+{ }_{n t}+\varepsilon_{i, t} \text { (7) }
$$

where $\dot{y}_{i, t}$ is the growth rate of output per worker, $y_{i, t}$ is a measure of the initial level of output per worker, $i_{i, t}$ is a measure of physical capital input constraints, $n_{i, t}$ is a measure of labor input constraints, $h_{i, t}$ is a measure of human capital per capita, $x_{i, t}$ is a measure of exports, $I(\bullet)$ is the indicator function, $q_{i, t}$ is one of the possible threshold variables, $\gamma^{\prime}$ is the threshold value, $\mu_{i}$ and $\eta_{t}$ are country and time specific effects, $\varepsilon_{i, t}$ is the error term assumed to be independent and identically distributed (iid) with mean zero and finite variance $\sigma^{\prime 2}$, and the subscripts $i$ and $t$ refer to country and period, respectively.

\section{Empirical Results}

\subsection{Data Sample and Sources}

The gross data comes mainly from the Penn World Tables v.6.2 (Heston et al., 2006) and refers to the constant prices entries in the period 1974-2003 for 72 countries (see Appendix A), averaged on a five years basis. The time series behavior of the focused variables gave us directions on the appropriate procedure for the five-year averaging of the data. Using several panel unit root tests, the non-rejection of the difference stationary hypothesis has leaded us to the procedure of directly averaging the growth rates of the variables by taking its five-year means.

Following Wössmann (2003), we have constructed two distinct measures of human capital stock, both based on the Mincerian human capital theory with decreasing returns to education. These two measures were constructed using the number of average schooling years by educational level obtained from the Barro and Lee (2000) Dataset. While the first measure (Eq. 8) assumes identical quality of education, the second (Eq. 9) accounts for quality differentials in education between countries. As educational quality measure we used the General Index of Qualitative Indicators of Human Capital (QIHC-G) recently built by Altinok and Murseli (2007). 


$$
\begin{aligned}
H_{i t}^{M} & =e^{\sum_{r_{a} s_{a i t}}} \\
H_{i t}^{O} & =e^{\sum_{r_{a} Q_{i} s_{a i t}}}
\end{aligned}
$$

where $r_{a}$ is the rate of return to education at level $a, s_{a i t}$ is the average years of schooling at level $a$ for country $i$ and period $t$, and $Q_{i}$ is the QIHC-G for country $i$.

Two additional observations are important to mention about the construction of these human capital stocks series. First, as justified by Wössmann (2003) the rates of return to education are considered to be the same for all countries. These rates come from the estimates of the world-average social rates of return to education by Psacharopoulos (1994) corresponding to $20.0 \%$ at the primary level, $13.5 \%$ at the secondary level, and $10.7 \%$ at the higher level. Second, the restricted availability of data on educational quality makes our measure of human capital stocks subject to the hypothesis that the differentials in the quality of education between the countries under analysis remained constant over the period.

In order to choose the best proxy measures for each of the theoretical explanatory variables of equation (7), we carried out a proxy-variable search procedure (Galimberti, 2009), which produced the following results (with expected signs in brackets): the log of the real GDP per worker in the previous year (-); the log of the share of investment in output (+); the labor force growth $(-)$; the stock of human capital per capita in the previous period (+); and the product between exports to GDP ratio and exports growth (+). Notice that the result for the human capital measure relates to the endogenous growth models specification of the human capital and the best adjust obtained from its delayed measure indicates the presence of endogeneity in its determination. 


\subsection{Panel Linear Specification Results}

As a benchmark for the panel threshold regressions (PTR) results, we first estimate the panel linear case. The results in Table 1 are divided in two samples, where the second sample includes only those countries where the QIHC-G variable is available.

Notice that all the coefficient estimates are statistically significant and in accordance with the expected signs. To interpret these results we pursue a comparative analysis of the variables coefficient estimates between the samples. For the initial output per worker slope coefficient, bigger absolute values imply a faster convergence to the steady state growth path. Thus, the results indicate that accounting for quality of education on the human capital measure slightly raises the rate of conditional convergence.

The results for the investment rate indicate that an increase of $1 \%$ in the investment rate is related to an increase of 2.46 and 1.76 percent points in the growth rate for the first and the second sample respectively. For the labor force growth variable notice that using the quality-adjusted measure of human capital the labor variable slope estimate become greater in absolute value. Thus, when the educational quality differentials are taken into account, the physical capital estimated effects on growth is lower and the effects of the labor force constraint become more pronounced. Besides, the quality-adjusted human capital measure presented a higher covariance with growth than the non-adjusted measure. This quality-adjusted human capital specification also leaded to a greater fit to the data as it can be inferred comparing the Akaike adjustment measures.

Finally, the exports variable appears to have a robust influence on growth, although considering the quality-adjusted measure of human capital lowers the estimated magnitude of this effect. Anyway, the results based on a simple analysis of variance (ANOVA) for the estimated equation show that the exports variable has the highest share in term of explanatory power on both samples/ specifications. At this point, and considering this relevance of the exports effects on growth, one may ask: what could be conditioning (determining) this quite strong relationship between exports and growth? To approach this issue we use panel threshold regressions and present the results in what follows. 
TABLE 1. PANEL LINEAR SPECIFICATION RESULTS

\begin{tabular}{|c|c|c|c|c|}
\hline Variables and Tests & $\begin{array}{c}\text { First } \\
\text { Sample }\end{array}$ & ANOVA $^{(1)}$ & $\begin{array}{l}\text { Second } \\
\text { Sample }\end{array}$ & ANOVA $^{(1)}$ \\
\hline $\begin{array}{l}\text { Initial Output per worker } \\
\ln \left(y_{i, t-1}\right)\end{array}$ & $\begin{array}{l}00.0452 \\
(-5 \cdot 96)^{* * *}\end{array}$ & $2.82 \%$ & $\begin{array}{c}-0.0484 \\
(-4.82)^{* * *}\end{array}$ & $2.98 \%$ \\
\hline $\begin{array}{l}\text { Investment rate } \\
\ln \left(I_{i, t}\right)\end{array}$ & $\begin{array}{c}0.0246 \\
(3.80)^{* * * *}\end{array}$ & $16.31 \%$ & $\begin{array}{c}0.0176 \\
(3.67)^{* * *}\end{array}$ & $10.59 \%$ \\
\hline $\begin{array}{l}\text { Labor force growth } \\
n_{i, t}\end{array}$ & $\begin{array}{l}-0.5357 \\
(-1.97)^{* * *}\end{array}$ & $4.38 \%$ & $\begin{array}{c}-0.7474 \\
(-2.82)^{* * * *}\end{array}$ & $7.18 \%$ \\
\hline $\begin{array}{l}\text { Mincerian Human Capital } \\
H_{i, t-1}^{M}\end{array}$ & $\begin{array}{l}0.0047 \\
(1.94)^{* * *}\end{array}$ & $2.19 \%$ & --- & --- \\
\hline $\begin{array}{l}\text { Quality-adjusted Human Capital } \\
H_{i, t-1}^{Q}\end{array}$ & --- & --- & $\begin{array}{l}0.0100 \\
(2.96)^{* * * *}\end{array}$ & $5.63 \%$ \\
\hline $\begin{array}{l}\text { Exports } \\
\dot{X} \cdot X / Y\end{array}$ & $\begin{array}{l}0.5985 \\
(6.89)^{* * * *}\end{array}$ & $20.78 \%$ & $\begin{array}{l}0.4942 \\
(6.15)^{* * * *}\end{array}$ & $19.47 \%$ \\
\hline Cross-section Effects Test ${ }^{(2)}$ & FFixed & $6.46 \%$ & FFixed & $6.57 \%$ \\
\hline Period Effects Test ${ }^{(2)}$ & NNone & --- & NNone & --- \\
\hline Observations $(N \times T)$ & $772 \times 6$ & --- & $557 \times 6$ & --- \\
\hline R-squared & 0.5294 & --- & 0.5242 & --- \\
\hline F-statistic & $5.25^{* * *}$ & --- & $5.06^{* * *}$ & --- \\
\hline Akaike information criterion & -4.8307 & --- & -5.0112 & --- \\
\hline
\end{tabular}

Notes: t-statistics are reported in brackets. All estimatives use White Heteroscedasticity consistent standard errors and covariance. ${ }^{*},{ }^{* *},{ }^{* * *}$ indicate unilateral statistical significance at the 10,5 and 1 percent level respectively. (1) Shares relative to the sum of squared deviations of the dependent variable. (2) The crosssection and period effects specification were tested using a Likelihood Ratio test to detect redundant fixed effects. 


\subsection{Panel Threshold Specification Results}

The PTR specification (7) to the ELG hypothesis is estimated considering three possible thresholds: the initial level of output per worker, the human capital measures, and the ratio of exports to GDP. We restrict our focus to searching for one to three multiple thresholds, resulting in a maximum of four regimes that can be reached.

The first step of the estimation procedure is to test for the existence of threshold effects. This test follows Hansen (1999) and the F statistic is obtained by bootstrapping techniques. The results are presented in Table 2, where significant threshold effects are found only for the initial output per worker and the Mincerian human capital. The threshold estimated values and the respective coefficients for the exports variable over the different regimes are presented in Table 3 .

TABLE 2. TESTS FOR THRESHOLD EFFECTS

\begin{tabular}{l|r|r|r}
\hline \multirow{2}{*}{ Threshold Variable } & \multirow{2}{*}{ Sample } & \multicolumn{2}{|c}{ Single Threshold } \\
\cline { 3 - 4 } & & $\mathrm{F}_{1}$ & \multicolumn{1}{c}{$\mathrm{p}$-value ${ }^{(1)}$} \\
\hline $\begin{array}{l}\text { Initial Output per worker } \\
\ln \left(y_{i, t-1}\right)\end{array}$ & $1^{\text {st }}$ & 18.54 & 0.0250 \\
\cline { 2 - 4 } $\begin{array}{l}\text { Mincerian Human Capital } \\
H_{i, t-1}^{M}\end{array}$ & $2^{\text {nd }}$ & 5.79 & 0.5390 \\
\hline $\begin{array}{l}\text { Quality-adjusted Human Capital } \\
H_{i, t-1}^{Q}\end{array}$ & $1^{\text {st }}$ & 28.36 & 0.0040 \\
\hline $\begin{array}{l}\text { Exports share on GDP } \\
X / Y\end{array}$ & $2^{\text {nd }}$ & 8.12 & 0.3830 \\
\cline { 2 - 4 } & $1^{\text {st }}$ & 9.13 & 0.2180 \\
\hline
\end{tabular}

TABLE 2 (continuation). TESTS FOR THRESHOLD EFFECTS

\begin{tabular}{l|r|r|r|r}
\hline \multirow{2}{*}{ Threshold Variable } & \multicolumn{2}{|c|}{ Double Threshold } & \multicolumn{2}{c}{ Triple Threshold } \\
\cline { 2 - 5 } & \multicolumn{1}{c|}{$\mathrm{F}_{2}$} & \multicolumn{1}{c}{$\mathrm{p}$-value ${ }^{(1)}$} & \multicolumn{1}{c}{$\mathrm{F}_{3}$} & $\mathrm{p}$-value $^{(1)}$ \\
\hline $\begin{array}{l}\text { Initial Output per worker } \\
\ln \left(y_{i, t-1}\right)\end{array}$ & 13.99 & 0.0520 & 12.69 & 0.1830 \\
\cline { 2 - 5 } $\begin{array}{l}\text { Mincerian Human Capital } \\
H_{i, t-1}^{M}\end{array}$ & 10.96 & 0.0950 & 2.63 & 0.9060 \\
\hline $\begin{array}{l}\text { Quality-adjusted Human Capital } \\
H_{i, t-1}^{Q}\end{array}$ & 7.18 & 0.9910 & 1.68 & 0.9950 \\
\hline $\begin{array}{l}\text { Exports share on GDP } \\
X / Y\end{array}$ & 6.79 & 0.3590 & 5.09 & 0.5210 \\
\cline { 2 - 5 } & 3.70 & 0.7580 & 6.83 & 0.2630 \\
\hline
\end{tabular}

Notes: The specifications where threshold effects are found to be significant are in bold.

(1) p-values obtained by 1000 bootstrap replications. 
TABLE 3. THRESHOLD AND EXPORTS SLOPE COEFFICIENT ESTIMATES OVER THE REGIMES

\begin{tabular}{|c|c|c|c|c|}
\hline \multirow{2}{*}{$\begin{array}{l}\text { Threshold } \\
\text { Variable }\end{array}$} & \multicolumn{4}{|c|}{ Thresholds } \\
\hline & No & Value & Perc. & $\begin{array}{l}95 \% \text { Conf. } \\
\text { Interval }\end{array}$ \\
\hline \multirow{2}{*}{$\begin{array}{l}\text { Initial Output } \\
\text { per worker }\end{array}$} & 1 & 8.10 & $15^{\text {th }}$ & {$[7.93,8.24]$} \\
\hline & 2 & 8.53 & $20^{\text {th }}$ & {$[8.53,8.78]$} \\
\hline $\begin{array}{c}\text { Mincerian } \\
\text { Human Capital }\end{array}$ & 1 & 1.72 & $20^{\text {th }}$ & {$[1.49,1.73]$} \\
\hline
\end{tabular}

Notes: (1) t-statistics are calculated using White Heteroscedasticity consistent standard errors and covariance. All the coefficient estimates are statistically significant at the 1 percent level.(2) See Footnote 2 of Table 1. The explanatory power for the other explanatory variables remained approximately the same as on the linear specification estimates.

TABLE 3. (continuation) THRESHOLD AND EXPORTS SLOPE COEFFICIENT ESTIMATES OVER THE REGIMES

\begin{tabular}{c|c|r|r|r|r}
\hline $\begin{array}{c}\text { Threshold } \\
\text { Variable }\end{array}$ & Regimes & \multicolumn{1}{c|}{$\begin{array}{c}\text { Exports } \\
\text { Coeff. }\end{array}$} & t-stat \\
& $x_{i, t} I\left\{\ln \left(y_{i, t-1}\right)\right\} \leq 8.10$ & Obs. & ANOVA ${ }^{(2)}$ \\
\hline \multirow{2}{*}{$\begin{array}{c}\text { Initial Output } \\
\text { per worker }\end{array}$} & $x_{i, t} I\left\{8.10<\ln \left(y_{i, t-1}\right) \leq 8.53\right\}$ & 2.22 & 4.36 & 23 & $9,30 \%$ \\
\cline { 2 - 6 } & $x_{i, t} I\left\{8.53<\ln \left(y_{i, t-1}\right)\right\}$ & 0.51 & 6.97 & 342 & $13,83 \%$ \\
\hline \multirow{2}{*}{$\begin{array}{c}\text { Mincerian } \\
\text { Human Capital }\end{array}$} & $x_{i, t} I\left\{H_{i, t-1} \leq 1.72\right\}$ & 1.49 & 4.89 & 88 & $7,52 \%$ \\
\cline { 2 - 6 } & $x_{i, t} I\left\{1.72<H_{i, t-1}\right\}$ & 0.49 & 6.35 & 344 & $14,64 \%$ \\
\hline
\end{tabular}

Notes: (1) t-statistics are calculated using White Heteroscedasticity consistent standard errors and covariance. All the coefficient estimates are statistically significant at the 1 percent level.(2) See Footnote 2 of Table 1 . The explanatory power for the other explanatory variables remained approximately the same as on the linear specification estimates.

The first significant threshold variable, initial output per worker, divided the sample into three regimes, where the border values (and their related percentile over the sample) are: US $\$ 3,320\left(15^{\text {th }}\right)$ and US $\$ 5,086\left(20^{\text {th }}\right)$. Notice that the first threshold value is very close to the World Bank (2008) classification for the upper limit of lower middle income countries (US\$ $3,855)$. That evidence gives support to the fact that the relationship between exports and growth is stable for the countries in the category of low income and lower middle income countries. However, it also implies that the impact of exports on growth changes for countries in the middle and high income classification. In fact, the estimated coefficient for exports in this transitional regime indicates a stronger effect of exports on growth of about 4 times the effect for the other regimes. This transitional regime included the following countries (period): Cameroon (1974-83), China (1994-98), Republic of Congo 
(1974-83; 1994-98), India (1984-98), Indonesia (1974-78), Pakistan (197488), Senegal (1984-93), Sierra Leone (1974-78; 1984-93), Sri Lanka (1974-83), Syria (1974-78), and Thailand (1974-83).

In the case of the second significant threshold variable - the human capital measure - the sample was divided into two regimes, where the switching regime value is 1.72 ( $20^{\text {th }}$ percentile). The estimated coefficient for exports indicates that countries with low human capital levels have stronger effects of exports on growth, such effects being about 3 times greater than for the countries with high human capital levels. This regime with a stronger effect of exports on growth included the following countries (period): Benin (1974-03), Brazil (1979-83), Cameroon (1974-93), China (1974-78), Republic of Congo (1974-88), Egypt (1974-88), El Salvador (1974-83), Guatemala (1974-93), Honduras (1974-88), India (1974-83), Kenya (1974-83), Malawi (1974-88; 1994-04), Mali (1974-04), Nepal (1974-04), Nicaragua (1974-78), Pakistan (1974-93), Portugal (1974-83), Rwanda (1974-04), Senegal (1974-04), Sierra Leone (1974-04), Syria (1974-83), Tanzania (1979-88; 1994-04), Tunisia (1974-88), Turkey (1974-83), Zimbabwe (1974-93).

This last result may seem contradictory to the idea that ELG would benefit from human capital through gains in technological absorption efficiency. However, the results show that the ratios of exports to GDP are significantly lower for the first regime (21\%) against the second regime (31\%). Therefore, although no statistically significant threshold was found for the exports share measure, the result for the human capital threshold can be related to diminishing returns to exporting.

FIGURE 1. DISTRIBUTION OF ESTIMATED ELG REGIMES THROUGH PERIODS

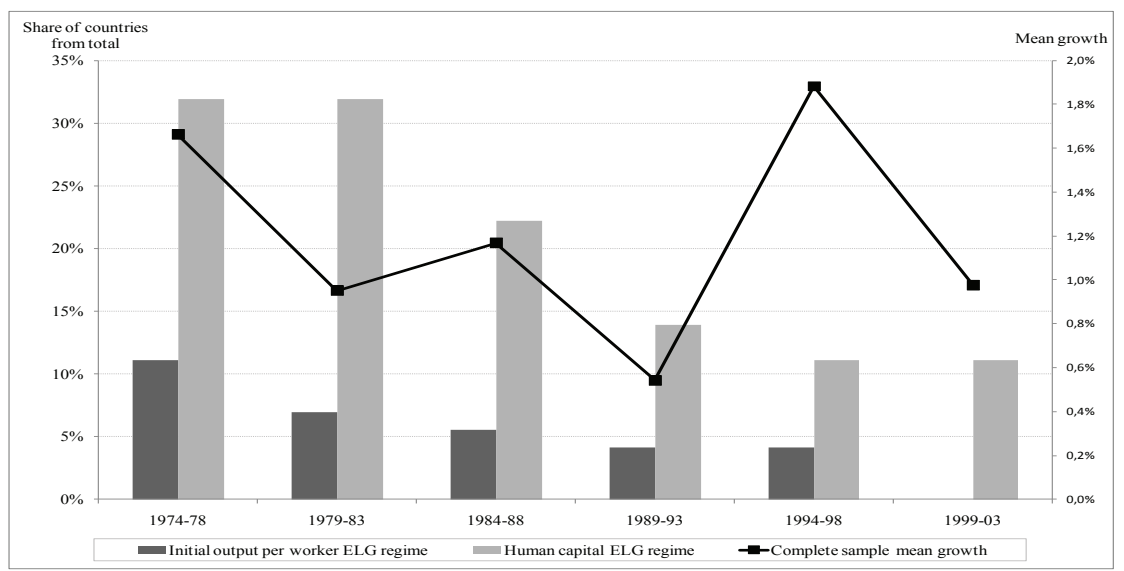

Source: prepared by the author. 
Finally, an interesting picture derived from these results is presented in Figure 1. If we denote ELG regimes as those where exports have a stronger effect on growth, we are able to see that the occurrence of ELG evidence is not only decreasing over time but also unrelated to the mean growth rate by period. This result may come as an explanation for the non-robustness to sample period found in many papers dealing with the exports-growth relationship, as surveyed by Giles and Williams (2000). Whether the relationship is found to be statistically insignificant, it might not be the case that the relationship does not actually exists, but that its conditioning factors (lower middle income and low human capital stocks) are not there anymore.

\section{Conclusions}

This paper provides some new evidence on the export-led growth hypothesis based on recently built panel threshold estimation techniques. Based on a comprehensive sample of 72 countries in the period 1974-2003, we found that the relationship between exports and growth is conditioned by countries initial levels of output and human capital. Stronger positive effects of exports on growth were found for countries in a transitional regime between the low and high income countries. Such result indicates the relevance of outwarddirected production to accelerate income convergence among countries. This conclusion was also corroborated by the result that the exports effect on growth decreases over time.

A strong ELG regime was also found for countries with lower human capital levels. That result can be reasoned based on the high correlation between human capital and share of exports to GDP, and, therefore, linked to the hypothesis of diminishing returns to exporting. Finally, it is worth noticing that, in respect to the role of educational quality differentials, we found evidence in favor of the superiority of the quality-adjusted measure of human capital stock against the measure adjusted for the returns to education. 


\section{References}

ALTINOK, N.; MURSELI, H. (2007). "International database on human capital quality”. Economics Letters, 96; p. 237-244.

AHUMADA, H.; SANGUINETTI, P. (1995). "The Export-Led Growth Hypothesis Revisited: Theory and Evidence”. Estudios de Economía, 22(2); p. 327-355.

BARRO, R. J.; LEE, J. (2000). "International Data on Educational Attainment: Updates and Implications". Cid Working Paper, 42.

CAPOLUPO, R. (2009). "The New Growth Theories and Their Empirics after Twenty Years". Economics: The Open-Access, Open-Assessment E-Journal, 3, 2009-1.

CRESPO-CUARESMA, J.; WÖRZ, J. (2005). “On export composition and growth”. Review of World Economics, 141(1); p. 33-49.

EDWARDS, S. (1989). "Openness, outward orientation, trade liberalization and economic performance in developing countries”. NBER Working Papers, 2908.

EDWARDS, S. (1991). "Trade orientation, distortions and growth in developing countries”. NBER Working Papers, 3716.

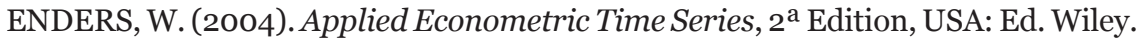

FEDER, G. (1983). “On exports and economic growth”. Journal of Development Economics, 12; p. 59-3.

FOSTER, N. (2006). "Exports, Growth and Threshold Effects in Africa”. Journal of Development Studies, 42(6); p. 1056-1074.

FOSU, A. K. (1990). "Export composition and the impact of exports on economic growth of developing countries". Economic Letters, 34; p. 67-71.

FUNKE, M.; RUHWEDEL, R. (2001). "Export variety and export performance: empirical evidence from East Asia”. Journal of Asian Economics, 12(4) p. 493-505.

GALIMBERTI, J. K. (2009). “A Proxy-variable search procedure”. Economics Bulletin, 29(4); p. 2538-2548.

GILES, J. A.; WILLIAMS, C. L. (2000). "Export-led growth: a survey of the empirical literature and some non-causality results. Part 1 ” Journal of International Trade \& Economic Development, 9(3); p. 261-337.

GONZÁLEZ, A.; TERÄSVIRTA, T.; DIJK, D. (2005). "Panel Smooth Transition Regression Models”. SSE/EFI Working Paper Series, 604; p. 1-33.

GROSSMAN, G.; HELPMAN, E. (1991). Innovation and Growth in the Global Economy. Cambridge: MIT Press.

HANSEN, B. E. (1996). "Inference when a nuisance parameter is not identified under the null hypothesis". Econometrica, 64; p. 413-430.

HANSEN, B. E. (1999). "Threshold effects in non-dynamic panels: Estimation, testing, and inference”. Journal of Econometrics, 93; p. 345-368.

HERZER, D.; NOWAK-LEHMANN, F. D.; SILIVERSTOVS, B. (2006). "ExportLed Growth in Chile: Assessing the Role of Export Composition in Productivity Growth". Developing Economies, 44(3); p. 306-328. 
HESTON, A.; SUMMERS, R.; ATEN, B. (2006). Penn World Table Version 6.2. Center for International Comparisons of Production, Income and Prices at the University of Pennsylvania.

ISLAM, N. (1995). "Growth Empirics: A Panel Data Approach”. The Quarterly Journal of Economics, 110(4); p. 1127-1170.

KÓNYA, L. (2006). "Exports and growth: Granger causality analysis on OECD countries with a panel data approach". Economic Modelling, 23; p. 978-992.

LEWIS, W. A. (1955). The Theory of Economic Growth. Homewood: Illinois.

PSACHAROPOULOS, G. (1994). "Returns to Investment in Education: A Global Update”. World Development, 22; p. 1325-1343.

TEMPLE, J. (1999). “The New Growth Evidence”. Journal of Economic Literature, 37(1); p. 112-156.

THIRLWAL, A. P. (2000). "Trade, trade liberalisation and economic growth: theory and evidence". Economic Research Papers, 63, African Development Bank.

TONG, H. (1983). Threshold models in non-linear time series analysis. New York: Springer-Verlag.

WÖSSMANN, L. (2003). “Specifying Human Capital”. Journal of Economic Surveys, 17(3); p. 239-270.

WORLD BANK (2008). Country Classification: By Income. URL [on-line]: <http://go.worldbank.org/D7SNoB8YUo>. Accessed in: 30 Jan. 2009. 


\section{Appendix A: Country Sample}

\begin{tabular}{|c|c|c|}
\hline $\begin{array}{l}\text { Continent / } \\
\text { Income Class }\end{array}$ & $\begin{array}{l}\text { Low and Lower Middle Income } \\
\text { (obs. }=34 \text { ) }\end{array}$ & $\begin{array}{l}\text { Upper Middle and High Income } \\
\text { (obs. }=38 \text { ) }\end{array}$ \\
\hline $\begin{array}{c}\text { Africa } \\
\left(\mathrm{n} .^{\circ} \text { obs. }=19\right)\end{array}$ & $\begin{array}{l}\text { Benin (BEN), Cameroon (CMR), } \\
\text { Republic of Congo (COG)*, Egypt } \\
\text { (EGY), Ghana (GHA), Jordan (JOR), } \\
\text { Kenya (KEN), Malawi (MWI), Mali } \\
\text { (MLI), Rwanda (RWA)*, Senegal } \\
\text { (SEN), Sierra Leone (SLE)*, Syria } \\
\text { (SYR)*, Tanzania (TZA), Tunisia } \\
\text { (TUN), Zambia (ZMB), Zimbabwe } \\
\text { (ZWE). }\end{array}$ & Israel (ISR), South Africa (ZAF). \\
\hline $\begin{array}{c}\text { America } \\
\left(\mathrm{n} .^{\circ} \text { obs. }=19\right)\end{array}$ & $\begin{array}{l}\text { Bolivia (BOL), Colombia (COL), } \\
\text { Dominican Republic (DOM), El Sal- } \\
\text { vador (SLV)*, Guatemala (GTM)*, } \\
\text { Honduras (HND), Nicaragua (NIC)*, } \\
\text { Paraguay (PRY), Peru (PER)*. }\end{array}$ & $\begin{array}{l}\text { Argentina (ARG), Brazil (BRA), } \\
\text { Canada (CAN), Chile (CHL), } \\
\text { Costa Rica (CRI)*, Jamai- } \\
\text { ca (JAM)*, Mexico (MEX), } \\
\text { Panama (PAN)*, United States } \\
\text { (USA), Uruguay (URY). }\end{array}$ \\
\hline $\begin{array}{l}\text { Asia/Oceania } \\
\left(\text { n. }{ }^{\circ} \text { obs. }=16\right)\end{array}$ & $\begin{array}{l}\text { China (CHN), India (IND)*, Indo- } \\
\text { nesia (IDN), Nepal (NPL)*, Pakistan } \\
\text { (PAK)*, Philippines (PHL), Sri }^{*} \text { Lanka (LKA)*, Thailand (THA). }\end{array}$ & $\begin{array}{l}\text { Australia (AUS), Hong Kong } \\
\text { (HKG), Japan (JPN), Repub- } \\
\text { lic of Korea (KOR), Malaysia } \\
\text { (MYS), New Zealand (NZL), } \\
\text { Singapore (SGP), Turkey (TUR). }\end{array}$ \\
\hline $\begin{array}{c}\text { Europe } \\
\left(\mathrm{n} .^{\circ} \text { obs. }=18\right)\end{array}$ & & $\begin{array}{l}\text { Austria (AUT), Belgium (BEL), } \\
\text { Denmark (DNK), Finland (FIN), } \\
\text { France (FRA), Germany (GER), } \\
\text { Greece (GRC), Hungary (HUN), } \\
\text { Ireland (IRL), Italy (ITA), Neth- } \\
\text { erlands (NLD), Norway (NOR), } \\
\text { Poland (POL), Portugal (PRT), } \\
\text { Spain (ESP), Sweden (SWE), } \\
\text { Switzerland (CHE), United } \\
\text { Kingdom (GBR). }\end{array}$ \\
\hline
\end{tabular}

Notes: *Countries without data on the quality of education, which counts to 12 for the Low and Lower Middle Income Class and 3 for the Upper Middle and High Income Class.

Selection criteria: (i) data availability for the period from 1974 to 2003; (ii) exclusion of countries for which oil production is the dominant industry; (iii) exclusion of countries whose data receive a grade " $\mathrm{D}$ " from the Penn World Tables (Deaton and Heston, 2008); (iv) exclusion of countries whose populations in 1974 were less than one million. 
